\title{
IMPROVING STUDENT'S SPEAKING ACHIEVEMENT THROUGH GUIDED GRAMMAR IN POLITEKNIK KELAPA SAWIT BEKASI
}

\author{
Luluk Setyowati \\ Program of Physics Education, Faculty of Math and Natural Sciences, \\ University of Indraprasta PGRI \\ setyowatiluluk98@gmail.com
}

\begin{abstract}
Speaking is an important skill in language learning, it is the key of active communication. As teaching speaking is important aspect in language learning process, this is a crucial part of second language learning and teaching. Despite this fact, for many years, teaching speaking in Indonesian context has been undervalued and English language teachers have continued to teach speaking as a repetition of drills or memorization of dialogues. However, today's education world requires that the goal of teaching speaking should improve students' communicative skills. Only in this way, the students can express themselves depend on the social context. In this study, the researcher attempts to conduct a research about the use of guided grammar and its impact in speaking achievement for students of oil palm plantation processing technology program of Politeknik Kelapa Sawit Bekasi. The activities of learning grammar provide an excellent opportunity for the learners to develop this skill. The result shows that at the beginning of guided grammar, students' speaking ability is still very limited. But when the speaking assignments in guided grammar went on for quite a long time, students were getting used to speak in grammatically correct way. Students felt that their speaking skills had improved and had become better than before.
\end{abstract}

Key words: speaking achievement, grammar, language learning

\begin{abstract}
ABSTRAK
Berbicara merupakan suatu keterampilan yang penting dalam pembelajaran bahasa, suatu hal yang merupakan kunci dalam berkomunikasi secara aktif. Karena pengajaran berbicara merupakan aspek yang penting dalam proses pembelajaran bahasa, hal ini merupakan bagian yang sangat krusial dalam pembelajaran dan pengajaran bahasa. Terlepas dari kenyataan ini, selama bertahun-tahun, pengajaran berbicara di Indonesia telah diremehkan dan pengajar bahasa Inggris terus memberikan pengajaran dalam bentuk pengulangan dan hafalan dialog. Pendidikan dunia saat ini menghimbau bahwa tujuan pembelajaran dan pengajaran berbicara harus dapat meningkatkan kemampuan berkomunikasi siswa. Hanya dengan cara ini, siswa dapat mengekspresikan diri mereka sendiri sesuai dengan konteks sosial. Dalam penelitian ini, peneliti mencoba meneliti tentang penggunaan tata bahasa dan pengaruhnya pada kemampuan berbicara siswa program teknologi pengolahan perkebunan kelapa sawit Politeknik Kelapa Sawit Bekasi. Kegiatan pembelajaran tata bahasa memberikan peluang yang bagus bagi siswa untuk meningkatkan kemampuan ini. Hasil penelitian menunjukkan bahwa pada awal pembelajaran tata bahasa, kemampuan berbicara siswa masih sangat terbatas.
\end{abstract}


Namun pada saat tugas berbicara dalam pembelajaran tata bahasa berlangsung lama, siswa menjadi terbiasa untuk berbicara secara gramatikal. Siswa merasa bahwa kemampuan berbicaranya telah meningkat dan lebih baik dari sebelumnya.

Kata kunci: pencapaian kemampuan berbicara, tata bahasa, pembelajaran bahasa

\section{INTRODUCTION}

Speaking is the one of the important parts in English skills that should be mastered by students besides reading, writing and listening. The function of speaking skill is to express an idea, someone feeling, thought, and it express spontaneously by orally. Speaking is one of the language arts of talk as communication interaction with someone, and it is very difficult to master it. Speaking skill is having a closely relationship with listening skill, in speaking act, the students must be listening and then speak up, because speaking is not only remembering and memorizing the sentences in written but speaking is spontaneous to show the students idea by orally.

Speaking is an important skill in language learning, it is the key of active communication. Speaking is used by the general people to measure how well someone's ability in acquiring second language, moreover for the professional English teacher or candidate of teacher, speaking has become more important skill to overview ability in second language. According to Chaney and Burk (2013:3), "Speaking is the process of building and sharing meaning through the use of verbal and non verbal symbols in a variety of contexts. Speaking is a crucial part of second language learning and teaching". It means students should be able to communicate with the others to get or to share information and/or to express what they feel. According to Nunan (2011), success of mastering language is measured in terms of the ability to carry out a conversation in the (target) language. It implies that speaking is the indicator of mastering the language.

As teaching speaking is important aspect in language learning process, this is a crucial part of second language learning and teaching. Despite this fact, for many years, teaching speaking in Indonesian context has been undervalued and English language teachers have continued to teach speaking as a repetition of drills or memorization of dialogues. However, today's education world requires that the goal of teaching speaking should improve students' communicative skills. Only in this way, the students can express themselves depend on the social context. It is essential that language teachers pay great attention to teaching speaking.

Indeed, teaching speaking is not an easy task to do. There could be several difficulties met by the teacher in conducting teaching speaking. For example, the students from different social background who have different motivation in learning English. According to the researcher, there is close correlation between motivation and competence. The students who have high motivation have high competence in English. On the other hand, those who have low motivation tend to have low competence. Besides, the students' anxiety also becomes the hindrance in teaching speaking. Anxiety can be caused by their low language competence which is often called linguistic difficulty. The anxiety occurs when the students are afraid of making mistake or error in speaking. Based on 
the observation in Politechnic Bekasi, the students' anxiety could be seen when the students were doing speaking activities. They spoke with lower voice and looked like very nervous. In addition, they lacked confidence to speak naturally.

Furthermore, they also cannot speak based on their willingness because what they want to speak is structured by the teacher, in other words they just repeat the word that has been produced. Afterward, those problems make students get lazy or less ability to speak. Those cases are quite problematic considering that even though speaking is not included in final test, in daily teaching and learning activities it is involved in the scoring and become teachers' concern and consideration in determining whether or not the students pass the subject. Therefore, the researcher considers that it is very necessary to find out an alternative way to create suitable and interesting technique related to the students' condition.

The researcher thinks that there must be a way to solve students' difficulties in speaking English. There are many ways to help the students to overcome their difficulties in speaking English. Properly, the teacher ought to know the condition of class, the character of students and what the students need. So, the teacher can use the appropriate strategy during the learning process. The students must involve and active in the learning process. So that, it is important to vary the activities during the lesson in order to keep them on track and maintain the students' motivation. A strategy that can help the teacher give each student opportunity to practice their speaking ability, each student is required to participate and give contribution during the discussion process. According to
Harmer when the teachers want to encourage students to speak, they have to use communicative approach that avoids the concentration towards grammar and vocabulary but emphasizes on the significance of language function (Harmer, 2011). In other words, these activities will involve students in real communication, where the achievement of their communicative task is more important than the accuracy of language they are using.

In this study, the researcher attempts to conduct a research about the use of guided grammar in English language classrooms and its impact in speaking skill. The use of guided grammar in classroom is important because of its positive impact on students' proficiency level. Some students do not like to speak in the classroom. In addition, they do not have the opportunity to speak this language outside. Thus, if student do not practice English in the classroom, may be they do speak it never. Teachers can use guided grammar subject as a technical way to deal with students' problems in speaking. The activities of learning grammar provide an excellent opportunity for the learners to develop this skill, speaking several minutes in a well structured and grammatically correct sentence.

The linguistic knowledge in English consists of the ability to analyze and recognize the structural features and components in the language. These abilities are concerned with phonological, morphological, syntactic, and semantic issues. The building blocks of the communication are grammatical points which make the structure of a language. Before starting to speak many factors and components must be formed in a person's mind. First, the sounds should be matched with each other to shape different 
words. Second, these words need to be united together to form phrases, clauses, and at last sentences through which a particular meaning can be conveyed. Considering these facts, it can be said that it is probably impossible to communicate in a foreign language without knowing the grammatical rules and structures of the target language.

Language proficiency is a multidimensional construct which consists of different levels of abilities and domains (Carrasqillo, 2014). Speaking is an interactive process of constructing meaning that concerns producing, receiving and processing information (Brown, 2014; Burns and Joyce, 2012). Speaking skill is one of the major abilities that is somehow troublesome for english foreign language (EFL) learners. The ability to communicate in a new language-target language - based on its grammatical, contextual, social, and cultural rules, and variations are always difficult for EFL learners (Burns and Joyce, 2012).

Canale and Swain (2013) suggested that communicative competence includes grammatical competence, discourse competence, sociolinguistic competence, and strategic competence. Thus, it can be said that grammatical rules are one of the fundamental aspects of speaking skill. According to Scarcella and Oxford (2012): Grammatical competence is an umbrella concept that includes increasing expertise in grammar (morphology, syntax), vocabulary, and mechanics with regard to speaking, the term mechanics refers to basic sounds of letters and syllables, pronunciation of words, intonation, and stress.

This implies that the learners should understand English language structures accurately to become fluent. Swan (2013) believed that knowing how to build and use certain structures makes it feasible to communicate common types of meaning successfully. Without these structures, it is difficult to make comprehensible sentences. $\mathrm{He}$ stated that in some social contexts, serious deviance from native-speaker rules can put off integration and arouse prejudice - a person who speaks badly may be considered uneducated or stupid. The language competence means that one has a good command of grammar and words, and can speak, read and write in grammatical foreign or second language. In conversation, if someone made mistakes in his pronunciation, grammar or words spelling, it will lead to misunderstanding and tedium to others, and even spoil their relationship. Therefore, we should try to develop the students' ability of using language in communication in a correct way (Zhong-guo and Min-yan, 2012).

There are two points of views in speaking. One view is that the learner should make himself/herself understood regardless of the grammatical mistakes in the target language, whereas another view insists on correctness in every aspect of language. The former is known as the fluency-oriented approach in which the small grammatical or pronunciation errors are unimportant, especially in the early learning stages. In fact, too much emphasis on correcting them is considered harmful since it may impede the natural acquisition of spoken skills (Corbett, 2009).

As Palmer (2011) stated "It is grammar that makes language so essentially a human characteristic. For though other creatures can make meaningful sounds, the link between sound and meaning is for them of a far more primitive kind than it is for man, and the link for man is grammar". Batstone (2014) also emphasized the 
importance of grammar when he declared that if there were no grammar, language would be disorganized, leaving us seriously handicapped.

Thus, knowledge of grammar is usually considered to be the essential area of the language system around which the other areas revolve. Cook (2016:14) emphasized this point when he claimed that "However important the other components of language may be in themselves, they are connected to each other through grammar. Grammar is often called the computational system that relates sound and meaning, trivial in itself but impossible to manage without". In this case, grammar is known as an important coordinator of other components of language. By learning grammar and mastering grammar, students can wipe out the anxiety of producing the wrong sentences and can increase their self confident.

From the statements above, the researcher assumes that students speaking skills can be improved by guided grammar, an also then it will wipe out the anxiety of producing the wrong sentences and can increase their self confident. By increasing students speaking skills students will be easier in English learning process, it also benefits them when they are graduated. It will be more meaningful when students get involve actively, they will retain more course content for a longer time, and are able to apply that material in a broader range of context. Furthermore, to improve speaking skill, we need many students' talking.

In relating to the explanation above, the researcher formulated the research problem: Can students speaking achievement be improved by using guided grammar for students of oil palm plantation processing technology program of Politeknik
Kelapa Sawit Bekasi? The objective of this research was to prove whether or not students speaking achievement be improved by using using guided grammar for students of oil palm plantation processing technology program of Politeknik Kelapa Sawit Bekasi.

\section{METHOD}

This study uses a descriptive qualitative. It Concerns with descriptions, qualities and observations (Swetnam, 2009). This research will describe the implementation of guided grammar in class to improve students' speaking skills. The source of data in this research is devided into two; primary and secondary data. Primary data obtained from interview results, then secondary data are obtained from related literature and documents. The informants of this research are third semester students of oil palm plantation processing technology program of Politeknik Kelapa Sawit Bekasi. Students and lecturers' participation are involved in this research. The researcher recorded all activities related to the focus of research as the data to answer the research question.

\section{RESULTS AND DISCUSSION Guided Grammar to Improve Speaking Skills}

The mastery of speaking skills in English is a priority for many second or foreign language learners. Learners consequently often evaluate their success in language learning as well as the effectiveness of their English course on the basis of how well they feel they have improved in their spoken language proficiency. Speaking is one of the basic language skills that have to be mastered by English foreign learners due to its significant and its use for communication. It is very important to 
be able to speak English regarding that it is the most commonly accepted language in the world so that it will be very beneficial for those who comprehend it not only to improve their knowledge and skills but also easier for them to get a job. More than that, they will not find it difficult to communicate and interact with people around the world when they travel (Garg and Gautam, 2015).

The objectives of teaching speaking at Politeknik Kelapa Sawit Bekasi are to improve students' understanding of the English language skill and English is as a means of communication and to enable the students to be active in practicing English language. The communicative approach is deemed a success if students can express their meaning confidently and clearly. However, the fact is many students have difficulties in speaking because they are not used to it. To solve the problem, the lecturer gives students the opportunity to speak in guided grammar subject. Unlike English learning in general, which only revolves around memorizing grammar and vocabulary which makes students feel less enthusiastic and also makes students less practice. While good language mastery will be achieved if students do a lot of practice. When lecturers give students the opportunity to speak in guided grammar subject, it will make them memorizes the subject better then the conventional model when they just memorizing the tenses.

When learning grammar in guided grammar subject, each student is given role to speak in certain range of time, it can be individual speaking in front of class or indivual speaking in group. Based on the interview results the researcher obtained information that before students given commands to speak, lecturer gives students a moment of time for preparation. Giving the students much time to prepare their project can be useful to create a better result.

Students need all the time that teacher give them before speaking in order to increase their understanding about the topic. Before the lecture commands the student to speak, students are given time to write about a topic using good grammar that they just learn. In teaching grammar in the class, lecturer emphazise more about the example, so that the students can be more familiar and can memorize grammar well. For intances, when learning about past tenses, lecturer gave students many examples of past tenses senteces then after that the teacher invite students to make the other examples. Different from ordinary learning models who demand students to understand many subject at one time, the learning process is made with minimal matery but it emphasizes in giving examples so that student can understand and comprehent the matery well in their longterm memory. Usually, when students are given many materials in one time, it is possible that they understand and comprehent all the matery given, but not long after, they will forget about those materials because it is only remaining in their brains temporary in a short time.

Involving speaking assignment in grammar lesson, not only makes them memorize and comprehent the materials well, but also can increase their speaking ability. After the lecture finish given them the materials, then the lecture gave them assignment to write a particular topics using tenses that they just learnt. When the materials are not difficult enough so that there was much time left after the lecturer gave explanation, the lecturer will command the students to write script to speak in 
indivual in front of class. However, when the time is limited, the lecturer gave them time to write but then the students will not speak in front of class, but inside their group. The lecturer commands them to creat group consist of 4-5 students, when one of them do the speaking, the others listen carefully. When listen carefully, the students can recognize their friends' mistakes then after their friend finish speaking, the students can give comment.

By using this teaching models, it is not only makes them better in grammar subject but also in speaking. Students who feel anxiety to speak in the beginning, become more motivated because they can speak in grammatically correct way. In addition, some students feel that public speaking is a tense, difficult thing, and not everyone can do public speaking. Most students feel less capable and lack confidence in public speaking to many people to convey their ideas. So, initially students feel anxious about the speaking assignments given by the lecturers because they are not used to speaking in public especially using English and anxiousness can not make an English presentation. However, lecturers give them enough time to prepare and make them used to speak in every meeting.

At the beginning of guided grammar, students' speaking ability is still very limited. But when the speaking assignments in guided grammar went on for quite a long time, students were getting used to speak in grammatically correct way. After the guided grammar lesson, students felt that their speaking skills had improved and had become better than before. Some of those who were originally very difficult in speaking and often stammered during the speaking, slowly began to speak fluently. Students felt that the guided grammar had a positive impact on them and they were satisfied with the application to improve their speaking skills. They feel easy in speaking and their grammar mastery is increased. Thus it can be seen that guided grammar is effective to increase students speaking skills.

\section{CONCLUSION}

Based on the results and discussion above, it can conclude that guided grammar can improve student's speaking achievement for students of oil palm plantation processing technology program of Politeknik Kelapa Sawit Bekasi.

\section{REFERENCES}

Batstone, R. (2014). Grammar. Oxford University Press.

Brown, H. D. (2014). Teaching by Principles: An Interactive Approach to Language Pedagogy. Englewood Cliffs, NJ: Prentice Hall Regents.

Burns, A., \& Joyce, H. (2012). Focus on speaking. Sydney: National Center for English

Canale, M., \& Swain, M. (2013). Theoretical bases of communicative approaches to second language testing and teaching. Applied Linguistics, 1(1), 1-47.

Carrasqillo, A. L. (2014). Teaching bases of communicative approaches to second language teaching and testing. Applied Linguistics, 1, 1-47.

Chaney, A. L., \& Burk, F. L. (2013). Teaching Oral Communication. Boston: Allyn \& Bacon.

Cook, V. (2016). Second Language Learning And Language Teaching (4nd ed). Arnold

Corbett, J. (2009). What is grammar and how should we teach it? Retrieved from Developing Teachers.com.

Garg, S., \& Gautam, A. (2015). Learning English can change your life for the better. International Journal of English Language, Literature and Humanities, III(II). 
Harmer, J. (2011). The Practice of English Language Teaching (3rd ed.). Edinburgh: Longman.

Nunan, D. (2011). Language Teaching Methodology. New York: Prantice Hall Interra.

Palmer, F. (2011). Grammar. HazelZhong-guo, L., \& Min-yan, S. (2012). The Watson and Viney Ltd.

Scarcella, R. C., \& Oxford, R. L. (2012). The tapestry of language learning: The individual in the communicative classroom.

Boston, MA: Heinle \& Heinle.
Swan, M. (2013). Seven bad reasons for teaching grammar - and two good ones. English Teaching Professional, 7, 3-5

Swetnam, D. (2009). Writing Your Desertation. Oxford: Cromwell Press Ltd.

relationship between traditional English grammar teaching and communicative language teaching. US-China Education Review, 4(1), 62-65. 